\title{
THE EFFECT OF BLOCK COMPOST SAGO WASTE ORGANIC PLANTS (POLYBAG) ON COMPOSITION VARIATIONS
}

\author{
Mohamad Yasin ${ }^{*}{ }^{\circledR}$, , Erma Prihastanti 2 , Endah Dwi Hastuti 2 \\ ${ }^{* 1}$ Magister of Biology, Faculty of Science and Mathematics, Diponegoro University, Tembalang, \\ Semarang 50275, Indonesia \\ 2 Magister of Biology, Diponegoro University, Indonesia
}

DOI: https://doi.org/10.29121/IJOEST.v4.i4.2020.99

Article Type: Research Article

Article Citation: Mohamad Yasin, Erma Prihastanti, and Endah Dwi Hastuti. (2020). THE EFFECT OF BLOCK COMPOST SAGO WASTE ORGANIC PLANTS (POLYBAG) ON COMPOSITION VARIATIONS.

International Journal of Engineering Science Technologies, 4(4), 11-16. https://doi.org/10.29121/IJOEST.v 4.i4.2020.99

Received Date: 25 July 2020

Accepted Date: 31 August 2020

Keywords:

Sago Waste

Growing Media

Block Compost

\begin{abstract}
The use of polybags is not environmentally friendly because the polybags will be thrown away and become trash so the environment will be polluted. One way to reduce environmental pollution is to use compost blocks made from sago waste. Sago waste has nutrients that can be used as plant growth media. One of the developments of growing media from compost is to form it in the form of compact compost blocks. Block compost functions in plant nurseries, stimulating root and leaf growth. The purpose of this study was to determine the effect of the type of block compost sago waste as a growing medium on variations in composition. At the time of planting, seedlings can be directly planted with holes in compost blocks. Seedlings planted in block compost have better growth in the field than seedlings planted in polybags, so that block compost can be considered as an environmentally friendly alternative to polybags.
\end{abstract}

\section{INTRODUCTION}

One of the developments of growing media from compost and to reduce soil pollution caused by polybag waste is to form it in the form of compact compost blocks. Block compost functions in plant nurseries, stimulating root and leaf growth. Compost has been shown to have some positive effects on soil quality and can provide important functions as a source of nutrition for plants [1].

Composting is an alternative to recycling organic waste that can be degraded into organic fertilizer as agricultural nutrition [2]. Composting has various advantages because it is economical, comfortable and helps in landfilling to enrich the soil and eliminate pathogens from the soil. All composting techniques ultimately lead to wasteful treatments and turn them into useful products [3]. This compost block is more environmentally friendly because it does not need to use polybags and inorganic fertilizer so as to reduce pollution by plastics on the soil [4].

Land blocks are the best system I have found for planting seeds, blocks freeing farmers from plastic containers that have become very commonly used. European farmers sell base crops in blocks to customers, who transport them in their own containers [5].

(C) 2020 The Author(s). This is an open access article distributed under the terms of the Creative Commons Attribution License, which permits unrestricted use, distribution, and reproduction in any medium, provided the original author and source are credited. 
Block composting materials include peat, soil and compost. One compost that can be developed for block compost is sago industrial waste. Peat is a portion of plant residues that decompose with fiber and organic matter in it. Poor quality peat contains many stems and is very dusty, whereas better quality peat has more fiber and structure [5]. Fresh sago waste has pore size and is bigger than black sago waste, so it has the potential to store water and cause aeration.

Block compost made from fresh sago waste has imperfect properties, so that it can be categorized as immature compost, whereas block compost made from black sago waste can be categorized as mature compost, because it is decomposed and has a black color [4]. To find out the composition of compost blocks that are compact, durable and sturdy, it is necessary to do a durability test that is testing the physical properties which include relaxation tests and density tests in making compost blocks with a variety of different compositions. In this study compost sago waste blocks will be tested as a replacement media for polybags.

\section{MATERIALS AND METHODS}

\subsection{SAGO WASTE COLLECTION}

Sago waste was obtained from Plajan Village, Annual District, Jepara Regency. Sago waste taken is fresh sago waste and black sago waste that has been decomposed. Sago waste is taken using a shovel and put into a sack.
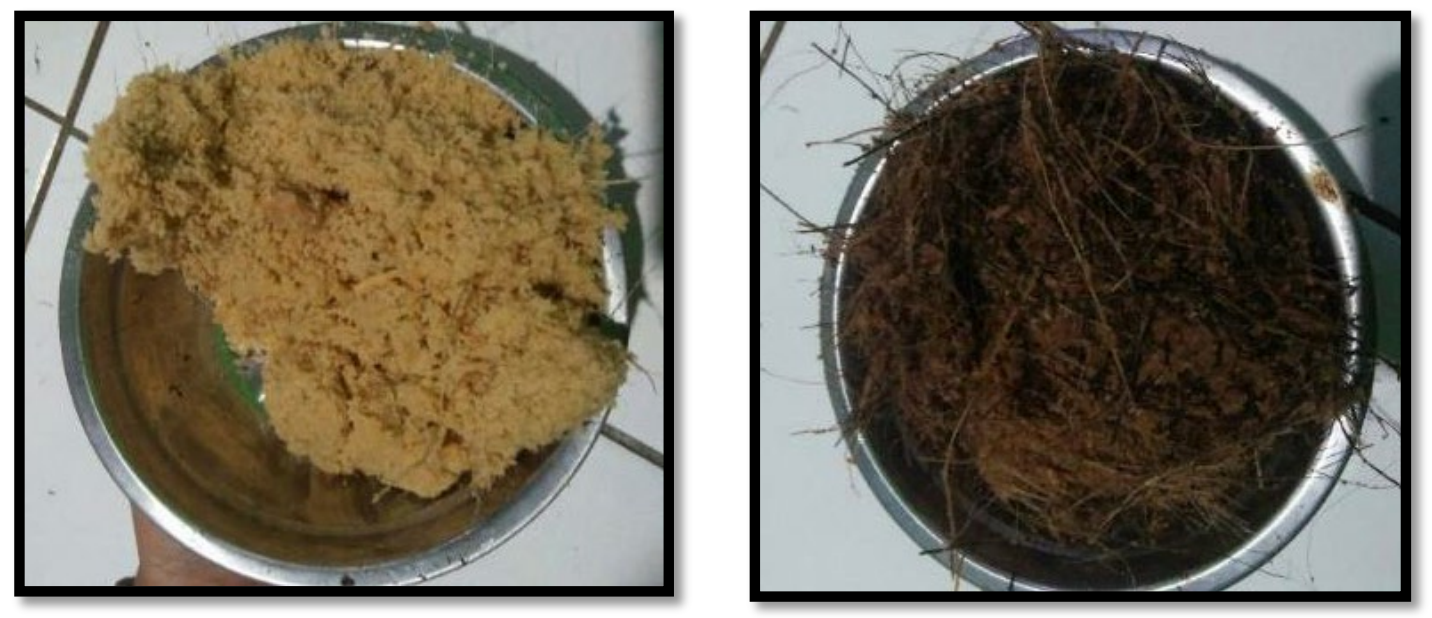

Figure 1: Sago waste

\subsection{DRYING SAGO WASTE}

Sago waste that has been obtained is then dried in the sun to dry. This is done to reduce water content in sago waste. Because if there is still water in the sago waste, it cannot be pressed into compost blocks.

Drying is then carried out with an oven at $69 \mathrm{o} \mathrm{C}$ for 1 hour to see the reduction in weight of the waste, then roasted 3 times to a constant mass. In order to ensure that sago waste is completely dry and can be pressed into compost blocks.

\subsection{SEPARATION OF POWDER AND SAGO WASTE FIBERS}

In the obtained sago waste, the composition of waste consists of coarse fibers and fine powder. Then the two are separated by sieving using a sieve and sorting. The fibers are cut short with scissors, so that when pressed in the process of making compost blocks can be compact. 


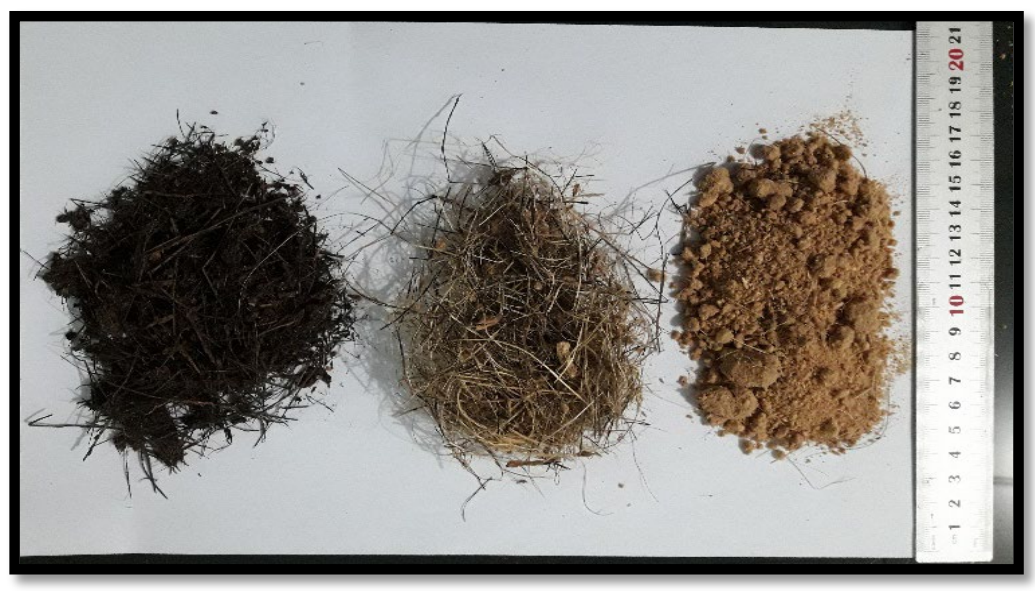

Figure 2: Separated sago waste

\subsection{MAKING COMPOST BLOCK WITH VARIOUS COMPOSITIONS}

The production of compost blocks with raw material for sago waste with various compositions is carried out by using press tools as follows:

1) Weighing various types of sago waste.

2) Weigh the starch and dissolve the starch with water according to the treatment.

3) Mixing sago waste that has been weighed with starch solution in the container. Then stir evenly with the aim of gluing the shape of the compost block.

4) Pressing the sago waste mixture mixed with starch solution in a press.

The composition details are as follows:

1) Soil (100 gr) + Starch (10gr) + Water (10ml)

2) Soil (100 gr) + Starch (20gr) + Water (20ml)

3) Land (100 gr) + Starch (30gr) + Water (30ml)

4) LSS (100 gr $)+$ Starch $(10 \mathrm{gr})+$ Water $(10 \mathrm{ml})$

5) LSS (100 gr) + Starch (20gr) + Water $(20 \mathrm{ml})$

6) LSS (100 gr) + Starch (30gr) + Water (30ml)

7) LSH (100 gr) + Starch (10gr) + Water (10ml)

8) LSH (100 gr) + Starch (20gr) + Water (20ml)

9) LSH (100 gr) + Starch (30gr) + Water $(30 \mathrm{ml})$

10) LSS (50 gr) + LSH (50 gr) + Starch (30gr) + Water (30ml)

11) LSS (25 gr) + LSH (75 gr) + Starch (30gr) + Water (30ml)

12) LSS (75 gr) + LSH (25 gr) + Starch (30gr) + Water (30ml)

13) LSS (40 gr) + LSH (40 gr) + Soil (20 gr) + Starch (30gr) + Water (30ml)

14) LSS (25 gr) + LSH (25 gr) + Soil (50 gr) + Starch (30gr) + Water (30ml).

Information:

LSS: fresh sago waste

LSH: black sago waste

\subsection{BLOCK COMPOST PRINTING}

Block compost printing is done by using a press tool. 


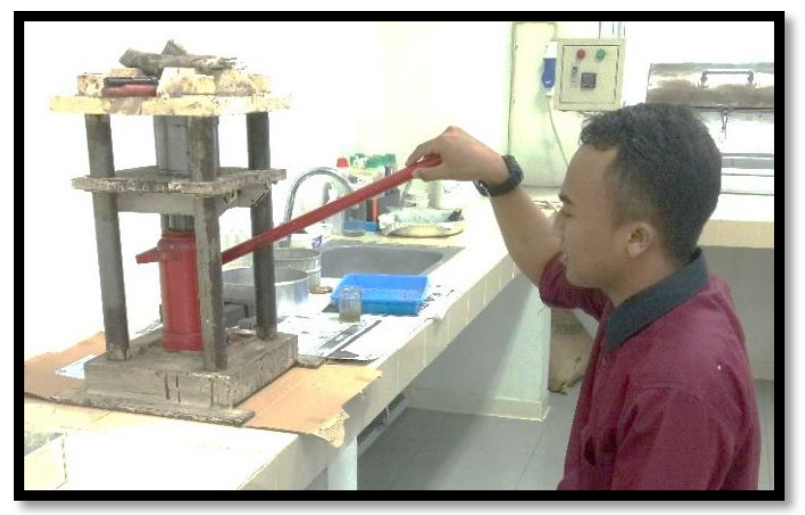

Figure 3: Process of compost printing

\section{RESULTS AND DISCUSSIONS}

Based on sago compost research [6], the sago compost content of both fresh and black content of N, P and $\mathrm{K}$ is relatively high, respectively $\mathrm{N}$ (1.32 to $1.67 \%), \mathrm{P}(0.15$ up to $0.47 \%)$ and $\mathrm{K}(1,39$ to $2.42 \%$ ) [6]. According to [7] sago waste that can be used as a planting medium consists of two types, namely fresh sago waste and black sago waste. Fresh sago waste is usually brownish yellow and has a long and strong fiber while black sago waste has a shorter and more brittle fiber structure compared to fresh sago waste.

Table 1: The basic ingredients of NPK in the growing media

\begin{tabular}{|c|c|c|c|}
\hline Media & $\mathrm{N}(\%)$ & $\mathrm{P}(\%)$ & $\mathrm{K}(\%)$ \\
\hline fresh sago waste & 1,44 & 0,46 & 2,22 \\
\hline Black sago waste & 1,12 & 0,05 & 1,29 \\
\hline
\end{tabular}

In Table 1. it can be seen that the sago waste which is used as a growing medium which is compacted into compost blocks has sufficient NPK nutrient content for plants.

This is in accordance with his research [6] that the basic elements of NPK are included in the macro element, meaning the elements needed by a plant in large numbers, although in this study no fertilizer was added but the media used contained NPK elements so that these elements could be help accelerate edamame growth. Fresh sago besides having a high NPK element also has a long fiber form and the composition is not too tight so that the water around the media is not too much.

The presence of water around the media that is not too much will cause the stability of the media moisture. Water in the media is utilized by plants optimally so that plants planted on fresh sago media can grow optimally. Black sago has a short form of fiber and its composition is rare, this causes the media to not be able to bind and store water properly so that the water given during the watering process is wasted out of the media in a short time as a result the media becomes dry quickly and plants lack water so that plant growth does not optimal.

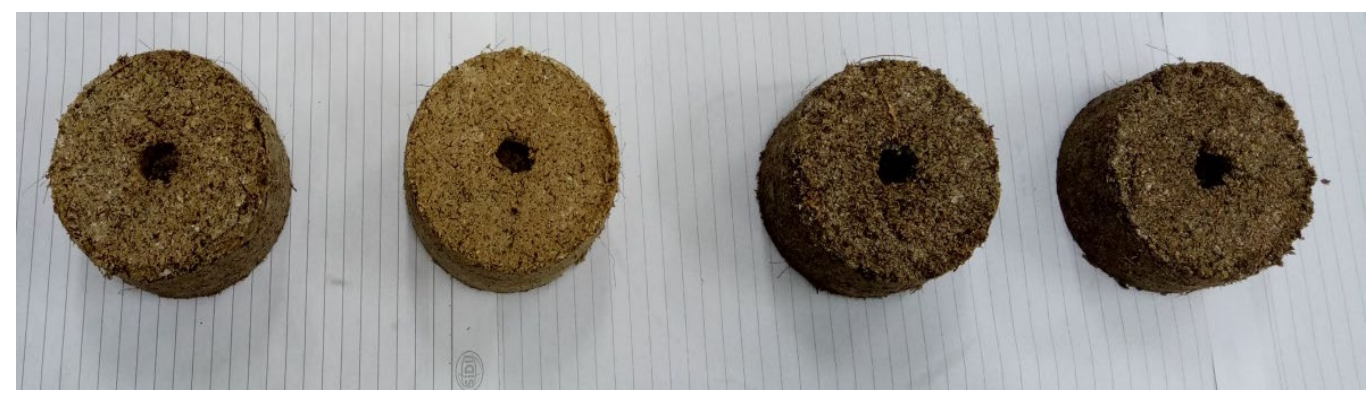

Figure 4: The printed sago waste

Block compost that is better used as a planting medium is one that has a maturity and has decomposed. Based on observations, compost sago blocks up to 45 days have not completely decomposed. This decomposition time is 
caused by the natural process without bio activator. Misra's research [8] revealed that composting straw with bio activators can reduce the composting period from 12 to 4 weeks. The physical signs of ripe compost are generally dark in color (black brown) and crumbly in texture, no longer visible in their original form [9].

\section{CONCLUSIONS AND RECOMMENDATIONS}

Sago Waste Compost Block has several advantages over polybags. These advantages include:

- The materials used in making block compost are materials that can decompose in the soil if planted in the field while polybags are made of plastic material that cannot be decomposed in the soil so that compost blocks are more environmentally friendly.

- Block Compost has two functions (dual functions), in addition to functioning as a poly bag, it is also a plant growing medium.

- Compost This block is not easily cracked and destroyed because it is printed with a press and compressed, making it easier for transportation to the field.

This Compost Block, besides having advantages, there are also drawbacks such as printed compost that cannot be planted directly but must be dried first. In addition, molds from compost blocks or compost blocks that are already dry cannot be stored in a place that is directly in contact with rain water or where it is submerged because it can cause spoilage or damage.

\section{SOURCES OF FUNDING}

This research received no specific grant from any funding agency in the public, commercial, or not-for-profit sectors.

\section{CONFLICT OF INTEREST}

The author have declared that no competing interests exist.

\section{ACKNOWLEDGMENT}

None.

\section{REFERENCES}

[1] C. A. Cambardella, T.L. Richard and A.E. Russel. "Compost Mineralization in Soil as a Function of Composting Process Conditions". European Journal of Soil Biology, vol. 39, pp. 117-127, 2003.

[2] A.K.C Ferreira, N.S. Dias, F.S.S. Junior, D.A.C. Ferreira, C.S. Fernandes, and T.S. Leite . "Composting of household organic waste and its effects on growth and mineral composition of cherry tomato ". Ambiente \& Água - An Interdisciplinary Journal of Applied Science, 2018.

[3] S. N. Chadar. Composting as an Eco-Friendly Method to Recycle Organic Waste. Department of Chemistry, University Institute of Technology - RGPV Bhopal, India. 2018.

[4] M. Pudjojono, and I. B. Suryaningrat, "Utilization of Coffee Processing Waste as Compost Block Organic Fertilizer" . Faculty of Agricultural Technology, University of Jember . 2008.

[5] E. Coleman, 2018. The New Organic Grower, 3rd Edition: A Master's Manual of Tools and Techniques for the Home and Market Gardener. Chelsea Green Publishing. 2018.

[6] E. Prihastanti. "Ultrastructure and Nutrient Content of Waste Sago and The Potential as Compost Block for Plant Growth Media". Faculty of Science and Mathematics, Diponegoro University, Semarang, Indonesia, 2015.

[7] Royani, KQ and E. Prihastanti. "Test the Use of Sago Waste as Planting Media for Orchid (Dendrobium sp.)." Bulletin of Anatomy and Physiology 1 (32), pp. 108-117, 2015. 
The Effect of Block Compost Sago Waste Organic Plants (Polybag) on Composition Variations

[8] R.V. Misra, R.N. Roy, and H, Hiraoka. "On farm Composting Methods" in Land and Water Discussion Paper, FAO Publication, Rome, 2003. 